\title{
Bank Specific and Macroeconomic Determinants of Commercial Bank Performance in Bangladesh
}

\section{Shakila Zerin Bony}

Assistant Professor, Department of Business Administration, Stamford University Bangladesh, Dhaka, BANGLADESH

*Corresponding Contact:

Email: bonyshakila@gmail.com

Manuscript Received: 25 July 2021

Accepted: 9 Oct 2021

\begin{abstract}
The main purpose of this study is to examine the impacts of bank-specific and macroeconomic factors on the commercial bank performance measures (ROA, NIM, and ROE in this case) in Bangladesh. The study identifies bank-specific characteristics and macroeconomic determinants of performance in Bangladesh's banking sector over the years 2009 to 2018. The study uses relevant data from a sample of 10 commercial banks in Bangladesh. The determinants are identified by using correlation and regression analysis. This finding serves as an indicator that the bank-specific and macroeconomic variables selected for this study provide a better description of ROA rather than net interest margin (NIM) and ROE. Among all the bank-specific determinants board size, audit committee meetings, and foreign ownership have a positive relationship with the bank's performance. Specifically, inflation and GDP are observed to have a positive relationship with bank performance. The findings of this research can be of great help to a wide range of entities such as academicians, bankers, the government, students, and investors. This study can be helpful to bank management by providing valuable information thus assisting in the construction of efficient management policy decisions in order to ensure higher profits.
\end{abstract}

Keywords: Bank performance, ROA, ROE, NIM, GDP, Inflation

This article is is licensed under a Creative Commons Attribution-NonCommercial 4.0 International License.

Attribution-NonCommercial (CC BY-NC) license lets others remix, tweak, and build upon work non-commercially, and

although the new works must also acknowledge \& be non-commercial.

\section{INTRODUCTION}

Because of the wide range of financial functions performed by the financial intermediaries, their role is of great significance to the growth of an economy. Among the various roles that financial intermediaries play in an economy, providing payment mechanism, facilitating a balance between demand and supply in the market, creating and dealing with complex instruments, performing risk management are of primary importance, Uzhegova (2010). 
Commercial banks are considered as the most significant financial intermediaries because they can offer a wide range of services some of which cannot usually be provided by other financial intermediaries, Swamy (2012). Commercial banks offer varied services to different lenders and borrowers. Since the introduction of liberalization policy in 1980, the banking sector in Bangladesh experienced a phenomenal growth. Before the liberalization policy, there were only four domestic banks (Sonali Bank, Pubali Bank, Rupali Bank, and Janta Bank) in Bangladesh and they were nationalized. There were only three foreign banks. The banking market was highly concentrated and dominated by four nationalized banks. However, due to extreme level of corruption, the profitability of the banking sector continued to be unsatisfactory.

Currently there are 58 scheduled commercial banks in Bangladesh composed of 8 state owned, 32 conventional private commercial banks, 8 Islamic Shariah based commercial banks and 10 foreign commercial banks. While the profits of a few commercial banks have been quite satisfactory, many of them are still struggling to survive in the competition, Swamy (2012). This poses a question: what are the macroeconomic variables that determine the profitability of commercial banks in Bangladesh? While there has been a lot of research on bank-specific and industry- specific determinants of bank profitability in Bangladesh, little light has been shed on the impacts of macroeconomic variables on the profitability of commercial banks in Bangladesh. This paper is motivated to estimate the impact of macroeconomic variables viz. GDP growth, Inflation and bank specific factors viz. Board Size, Number of Independent Directors, Audit Committee Functionality and Foreign Ownership on the performance of commercial banks in Bangladesh where ROA, NIM, ROE have been used as profitability measures.

\section{Objectives of the Study}

The study aims at examining the bank specific and macroeconomic determinants of the commercial bank performance in Bangladesh. The specific objectives are:

- To investigate the relationship between bank specific factors (board size, number of independent directors, audit committee functionality, foreign ownership) and performance of commercial banks in Bangladesh.

- $\quad$ To investigate the relationship between the macroeconomic factors (GDP \& Inflation) and performance of commercial banks in Bangladesh.

\section{LITERATURE REVIEW}

Naceur (2003) examined the determinants of the performance of Greek commercial banks from 1989 to 2000 . They measured the profitability of the commercial banks using the ratios of return on assets (ROA) and return on equity (ROE). They considered internal factors, like management policy decisions and external factors, like economic environment to explain the profitability of the banks. The results suggested that the variables related to management decisions assert a major impact on the profitability of Greek commercial banks.

Return on asset (ROA), captures the aspect of performance of a bank in terms of its profitability, it is the ratio of net income to total assets, Swamy (2012). It is a ratio that is directly affected by internal factors of a bank that are financial conditions of a bank, but as well as external factors to a bank such as economic conditions and government policies, Georgiou (2010). 
Return on Equity (ROE), measures the rate of return of ownership interest of common stock owners. It measures the efficiency in generating profit from every unit of equity ownership. It shows how best a firm uses investment fund in generating profit growth, Georgiou (2010).

Return on capital employed, is arguably similar to ROA but ROCE takes into account the sources of financing. It is the ratio of non-markup income to capital employed, Goddard et al. (2004).

Net interest margin (NIM), is a measure of the difference between interest income and interest expense relative to the value of the assets. It is as a rule articulated as a percentage of what the bank earns on loans and other assets in a time period minus the interest expensed on borrowed funds divided by the average value of the assets on which it earned income in that time period, Islam (2003).

Two macro-economic variables were used as control variables: inflation and GDP per capita growth. In Pakistan case, Ahmad (1994) set to examine the internal and external determinants of bank profitability on Greek banks for the period 1985-2001 by implementing the Generalized Method Moment (GMM) technique. They found out that the empirical outcomes of the regression are tied to bank-specific and macroeconomics determinants. Their study suggests that macroeconomic factors like real GDP growth rate and inflation rate have no important effect on profitability but the real interest does have a significant influence on profitability.

\section{DeVELOPMENT OF HyPOTHESES}

Theoretical framework is a basic conceptual structure organized around a theory. It defines the kinds of variables that are going to be used in the analysis. Following Figure 1 exhibits the theoretical framework for this study. Two independent variables namely GDP growth and Inflation are used here. Bank profitability is the dependent variable and three proxies to bank profitability are used in this study, namely return on equity (ROE), return on assets (ROA) and net interest margin (NIM).
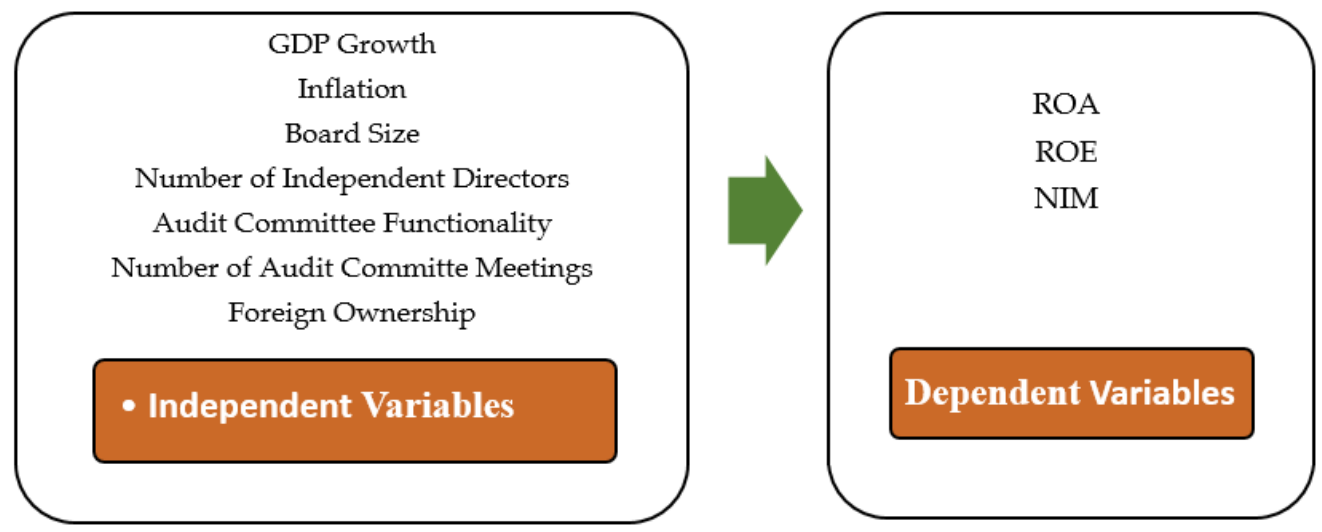

Figure 1: Theoretical Framework

This paper attempts to test seven hypotheses. A hypothesis is a supposition or proposed explanation made on the basis of limited evidence as a starting point for further investigation. In other words, a hypothesis is a claim or assumption about the value of a population parameter. It consists either of a suggested explanation for a phenomenon or of a reasoned proposal suggesting a possible correlation between multiple phenomena. 
According to Becker (1995), hypothesis testing is the process of judging which of two contradictory statements is correct.

Hypothesis 1: Bank profitability has a significant relationship with GDP growth. Hypothesis 2: Bank profitability has a significant relationship with inflation. Hypothesis 3: Bank profitability has a significant relationship with Board Size.

Hypothesis 4: Bank profitability has a minimal relationship with Number of independent directors.

Hypothesis 5: Bank profitability has a significant relationship Audit Committee Functionality.

Hypothesis 6: Bank profitability has a significant relationship Number of Audit Committee Meetings.

Hypothesis 7: Bank profitability has a significant relationship Foreign Ownership.

\section{ResearCh Methodology}

\section{Sample and Data}

The data set of this research will be comprised of financial statements of 10 DSE listed commercial banks of Bangladesh for the financial years 2009 to 2018 totaling to 100 financial statements. The banks were sampled using stratified sampling method in order for ensuring the inclusion of commercial banks from each category viz. private, public, conventional and Islamic banks. A list of the commercial banks selected for the research is delineated here.

Table 1: Selected Banks for the Research

\begin{tabular}{|c|l|c|l|}
\hline Sl. No. & \multicolumn{1}{|c|}{ Bank Name } & Sl. No. & \multicolumn{1}{|c|}{ Bank Name } \\
\hline 1 & Brac Bank Limited & 6 & Southeast Bank \\
\hline 2 & FSIBL & 7 & Uttara Bank \\
\hline 3 & Dhaka Bank Limited & 8 & Exim Bank \\
\hline 4 & Mercantile Bank Limited & 9 & Al-Arafah Islami Bank Limited \\
\hline 5 & The City Bank Limited & 10 & Jamuna Bank Limited \\
\hline
\end{tabular}

The data used for this study are from a pooled time-series cross-sectional data. Crosssectional data provide information on variables for a given period of time. While time series data give information about variables over a number of periods of time. The data for bank specific variables are obtained from bank websites and linked web portal. The data for macroeconomic variables are obtained from Bangladesh Bank database. The data are classified as panel data because it is a combination of cross-sectional and time series data. An advantage of using panel data is that more observations on the explanatory variables are available. This has the effect of helping overcome the inherent multicollinearity which probably exists between the independent variables. Most of past researches which studied on bank profitability used panel data to investigate the relationship between the performance measures. Haron (1996) used pooled time-series cross-sectional data for their study, which was taken from annual reports of Islamic banks from five countries namely Malaysia, Bangladesh, UAE, Jordan and Bahrain. The sample period for their study was from 1984 to 2002. Hasan (2004) also utilized cross-country bank level data to examine the performance indicators of commercial banks. The data was compiled from income statements and balance sheets of commercial banks in 21 countries for each year from 1994 to 2001. 


\section{Graphical Representation}

\section{Return on Asset}

Table 2: Average Return on Asset (2009-2018)

\begin{tabular}{|l|c|}
\hline Year & Average Return on Asset (ROA) \\
\hline 2009 & $1.20 \%$ \\
\hline 2010 & $1.29 \%$ \\
\hline 2011 & $1.80 \%$ \\
\hline 2012 & $1.04 \%$ \\
\hline 2013 & $0.57 \%$ \\
\hline 2014 & $0.70 \%$ \\
\hline 2015 & $0.85 \%$ \\
\hline 2016 & $1.03 \%$ \\
\hline 2017 & $0.97 \%$ \\
\hline 2018 & $0.66 \%$ \\
\hline
\end{tabular}

\section{Average ROA}

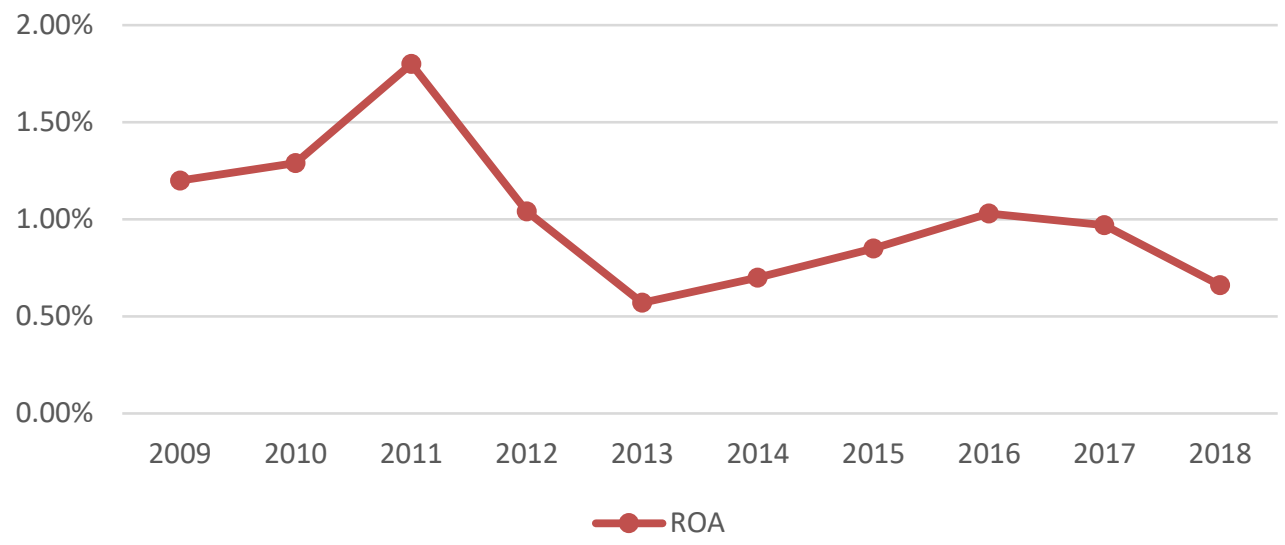

Figure 2: Average ROA

Here in the graph, we can see that average return on asset was higher in 2010. After then, average return on asset is decreasing. In 2015, average return asset was $1.03 \%$ and in 2018 , it decreases to $.66 \%$. Though our GDP is on the increase, average return on asset of commercial bank is decreasing because of the dishonest businessmen who take loan from the bank but don't pay properly. These people increase the Non-performing loan of the commercial bank which reduces the bank average return on asset.

\section{Return on Equity}

Table 3: Average Return on Equity (2009-2018)

\begin{tabular}{|c|c|}
\hline Year & Average Return on Equity (ROE) \\
\hline 2009 & $19.64 \%$ \\
\hline 2010 & $23.12 \%$ \\
\hline 2011 & $22.39 \%$ \\
\hline
\end{tabular}




\begin{tabular}{|l|l|}
2012 & $16.15 \%$ \\
\hline 2013 & $10.74 \%$ \\
\hline 2014 & $10.95 \%$ \\
\hline 2015 & $11.35 \%$ \\
\hline 2016 & $13.03 \%$ \\
\hline 2017 & $13.66 \%$ \\
\hline 2018 & $11.19 \%$ \\
\hline
\end{tabular}

\section{Average ROE}

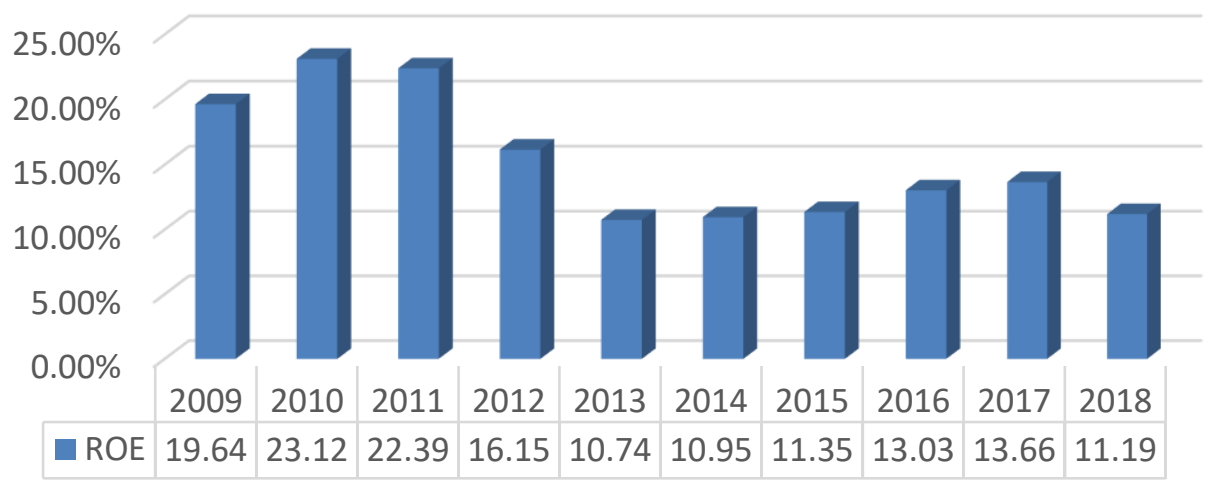

Figure 3: Average ROE

Here in the graph, we can see that average return on equity was higher in 2010. After then, average return on asset is decreasing. In 2017, average return equity was $13.66 \%$ and in 2018 , it decreases to $11.19 \%$. Though our GDP is on the increase, average return on equity of commercial bank is decreasing because of the dishonest businessmen who take loan from the bank but don't pay properly. These people increase the Non-performing loan of the commercial bank which reduces the bank average return on equity.

\section{Net Interest Margin}

Table 4: Average Net Interest Margin (2009-2018)

\begin{tabular}{|c|c|}
\hline Year & Average Net Interest Margin (NIM) \\
\hline 2009 & $2.58 \%$ \\
\hline 2010 & $2.32 \%$ \\
\hline 2011 & $2.71 \%$ \\
\hline 2012 & $2.62 \%$ \\
\hline 2013 & $2.53 \%$ \\
\hline 2014 & $2.07 \%$ \\
\hline 2015 & $2.21 \%$ \\
\hline 2016 & $2.09 \%$ \\
\hline 2017 & $2.17 \%$ \\
\hline 2018 & $2.06 \%$ \\
\hline
\end{tabular}




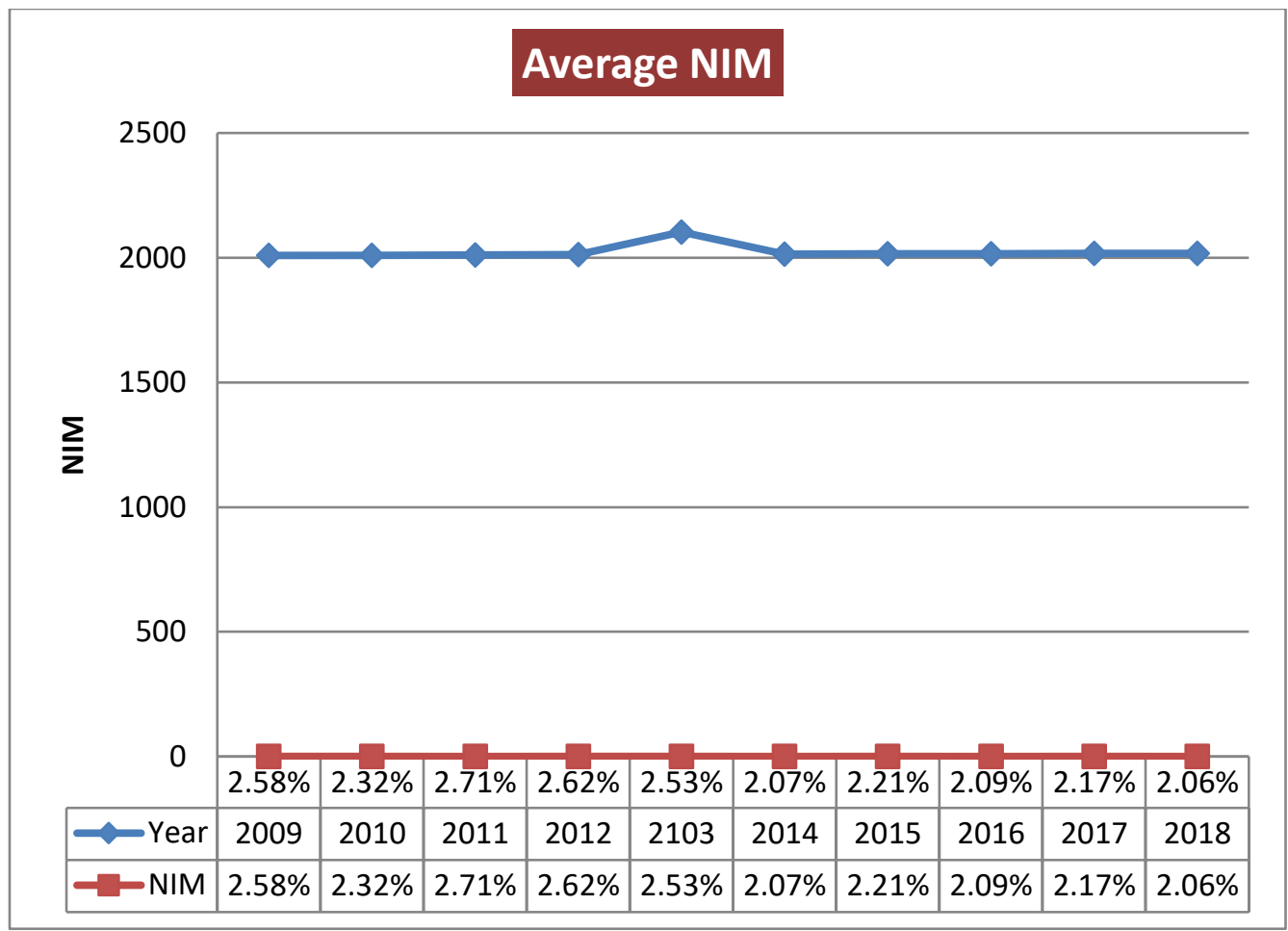

Figure 4: Average NIM

Here in the graph, we can see that average net interest margin was higher in 2011. After then, average return on asset is decreasing. In 2017, average net interest margin was $2.17 \%$ and in 2018, it decreases to $2.06 \%$. This graph indicates that the commercial banks of Bangladesh are not performing well in creating spread in recent years.

\section{Loan Growth}

Table 5: Loan Growth (2010-2018)

\begin{tabular}{|c|c|}
\hline Year & Average Loan Growth \\
\hline 2010 & $20.87 \%$ \\
\hline 2011 & $29.87 \%$ \\
\hline 2012 & $19.39 \%$ \\
\hline 2013 & $15.89 \%$ \\
\hline 2014 & $11.97 \%$ \\
\hline 2015 & $15.64 \%$ \\
\hline 2016 & $15.11 \%$ \\
\hline 2017 & $15.97 \%$ \\
\hline 2018 & $20.41 \%$ \\
\hline
\end{tabular}

Here in the graph, we can see that average return on equity was higher in 2011. After then, average return on asset is decreasing. In 2014, average return equity was $11.97 \%$. From 2015 , it started to increase. In 2018, the loan growth reaches to $20.41 \%$. As our GDP is on the increase, loan by the commercial bank is increasing. This is because the business is growing and the demand for loan is also growing. 


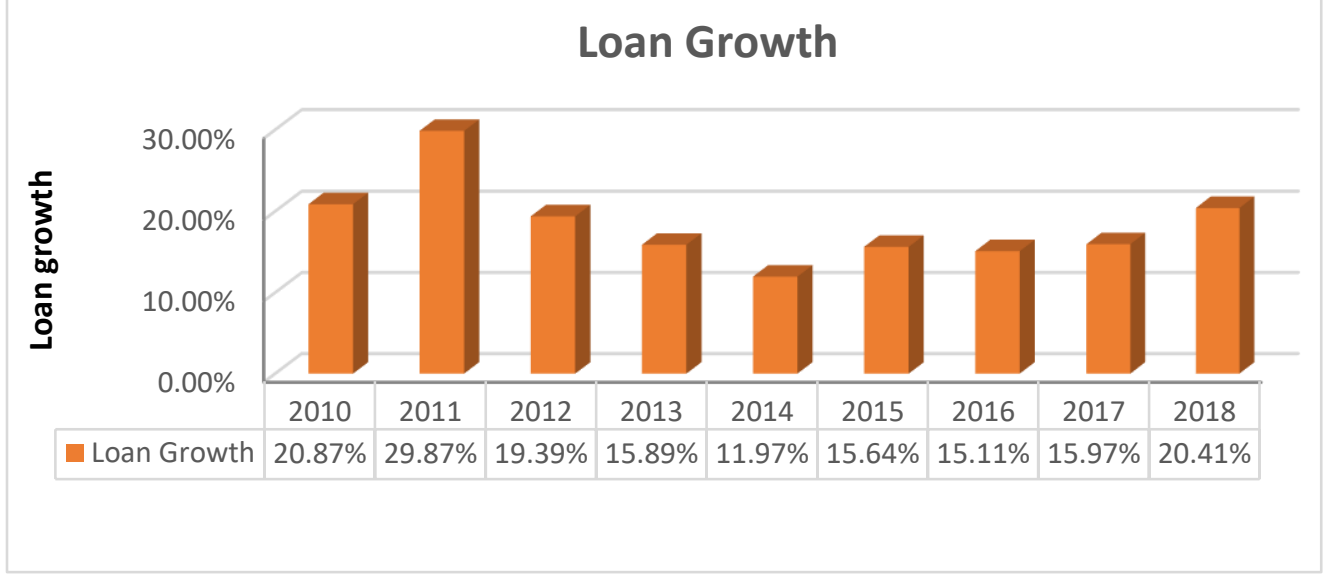

Figure 5: Loan growth

\section{ANALYSIS OF RESEARCH}

\section{Descriptive Statistics}

Descriptive statistics of the analysis show the pattern of the data used in the paper. Descriptive statistics are used to describe the basic features of the data in a study. They provide simple summaries about the sample and the measures. The table 6 shows the mean, standard deviation, minimum and maximum value for 9 variables used in the paper with 100 observations for each. The mean of return on asset is .010 with standard deviation of .016 indicating the tightness of data set in relation to the mean is not very dispersed. The mean of ROE is .152 while the standard deviation is .077 indicating that the values are tightly close to each other with insignificant deviation from the mean. The standard deviation against the mean of the variables for, NIM, FW, GDP and inflation are also insignificant. But in case of board size, independent director, audit committee meeting, standard deviation is greater than mean of the variables indicating the observations are highly dispersed and the range of values widely varies which is understandable from the minimum and maximum values of the observations. Detailed findings of the descriptive analysis are shown in the table below:

Table 6: Descriptive Statistics

\begin{tabular}{|c|c|c|c|c|c|c|c|c|c|}
\hline & ROA & ROE & NIM & BZ & IND & ACM & FW & GDP & INF \\
\hline Mean & .010093 & .1522355 & .0233607 & 14.84 & 1.596 & 7.724 & .0213376 & .06291 & .07273 \\
\hline Std. & .015897 & .0771054 & .0081741 & 4.286712 & 1.311359 & 4.43786 & .0832745 & .0064898 & .0179071 \\
\hline Min & -.108534 & .0017019 & -.001165 & 6 & 0 & 0 & 0 & .0505 & .0503 \\
\hline Max & .0509956 & $.616956-$ & .0443226 & 26 & 8 & 30 & .98 & .073 & .1081 \\
\hline
\end{tabular}

\section{Correlation Analysis}

From the Table 7, it is evident that there is a positive correlation of ROA with board size (BZ), audit committee functionality, audit committee meeting, number of independent director and foreign ownership. This indicates that with the increase in these variables, there has been increase in ROA. Board size has very strong positive correlation with ROA. On the other hand, GDP has strong negative correlation with ROA. 
Table 7: Correlation Matrix

\begin{tabular}{|l|c|c|c|c|c|c|c|c|c|c|}
\hline & ROA & ROE & NIM & BZ & ACF & IND & ACM & FW & GDP & INF \\
\hline ROA & 1 & & & & & & & & & \\
\hline ROE & $.2405^{*}$ & 1 & & & & & & & & \\
& .0001 & & & & & & & & & \\
\hline NIM & $.1863^{*}$ & $.2547^{*}$ & 1 & & & & & & & \\
& .0031 & .0000 & & & & & & & & \\
\hline BZ & $.3524^{*}$ & 0.1137 & -.0144 & 1 & & & & & & \\
& .0000 & .0728 & -.8205 & & & & & & & \\
\hline ACF & .0964 & $-.2908^{*}$ & -.0898 & -.0829 & 1 & & & & & \\
& .1285 & .0000 & .1569 & .1915 & & & & & & \\
\hline IND & .0028 & $-.3396^{*}$ & -.0492 & .0170 & $.6552^{*}$ & 1 & & & & \\
& .9647 & .0000 & .4386 & .7887 & .0000 & & & & & \\
\hline ACM & .0966 & -.1123 & .0979 & $.2464^{*}$ & $.2655^{*}$ & $.3417^{*}$ & 1 & & & \\
& .1278 & .0763 & .1266 & .0001 & .0000 & .0000 & & & & \\
\hline FW & .0384 & -.0015 & $.1934^{*}$ & -.0136 & .0607 & $.1914^{*}$ & .1081 & 1 & & \\
& .5455 & .9806 & .021 & .8304 & .3390 & .0024 & .0882 & & & \\
\hline GDP & $-.1259^{*}$ & $-.4064^{*}$ & -.1093 & $-.1285^{*}$ & $.3917^{*}$ & $.4929^{*}$ & $.2182^{*}$ & .1041 & 1 & \\
& .0467 & .0000 & .0845 & .0423 & .0000 & .0000 & .0005 & .1006 & & \\
\hline INF & .1063 & $.3089^{*}$ & $.1928^{*}$ & $.1510^{*}$ & $-.2330^{*}$ & $.4743^{*}$ & $-.1394^{*}$ & -.0898 & $-.5383^{*}$ & 1 \\
& .0936 & .0000 & .0022 & .0169 & .0002 & .0000 & .0275 & .1571 & .0000 & \\
\hline
\end{tabular}

Here, we can see that there is a positive correlation of ROE with inflation rate. This indicates that with the increase in inflation, there has been increase in ROE. On the other hand, board size, number of independent director in board, audit committee functionality and audit committee meeting have negative relationship with ROE. Audit committee functionality, independent director and GDP have very negative strong relationship with return on equity. Increase in these variables will decrease the return on equity.

Here, we can also see that there is a positive correlation of NIM with percentage of foreign ownership and inflation rate. This indicates that with the increase in foreign ownership and inflation, there has been increase in NIM. On the other hand, board size, number of independent director in board and audit committee functionality have negative relationship with NIM.

\section{Regression Analysis}

Model-1 shows the relationship between corporate governance and bank's performance (ROA). In this model, four control variables (Loan growth, AD ratio, Equity to total asset ratio, bank size) have also been included. From the Hausman test, we have found that the fixed effect model is appropriate for this model. Here, we can see that pob $>F=0.0000$ which means that the model is ok. On the other hand, $\mathrm{R}$ square indicates that $94.13 \%$ data of data can be predictable.

Model-2 shows the relationship between management quality and bank's performance. In this model, four control variables (Loan growth, AD ratio, Equity to total asset ratio, bank size) have also been included. From the Hausman test, we have found that the fixed effect model is appropriate for this model. Here, we can see that Prob $>\mathrm{F}=0.0000$ which means that the model is ok. On the other hand, R square indicates that $95.24 \%$ data of data can be predictable. 
In Model-3, we have tried to find the relationship among corporate governance, management quality and bank's performance. Here, we have found that better corporate governance and management quality increase the bank profitability.

In Model-4, we have considered the time effect and found same result as we found in model-3.

Table 8: Determinant of Bank Performance Measured by ROA

\begin{tabular}{|c|c|c|c|c|c|}
\hline Explanatory Variable & Model-1 & Model-2 & Model-3 & Model-4 & Model-5 \\
\hline \multicolumn{6}{|l|}{ Governance: } \\
\hline Board Size & $\begin{array}{l}.0005481^{*} \\
2.36\end{array}$ & & $\begin{array}{l}.0004986^{*} \\
2.20\end{array}$ & $\begin{array}{l}.0002044 \\
0.93\end{array}$ & $\begin{array}{l}.0004031 \\
1.73 \\
\end{array}$ \\
\hline $\begin{array}{l}\text { Audit Committee } \\
\text { Functionality }\end{array}$ & $\begin{array}{l}.0040686^{*} \\
2.15\end{array}$ & & $\begin{array}{l}.0041891^{*} \\
2.28\end{array}$ & $\begin{array}{l}.0039437^{*} \\
2.24\end{array}$ & $\begin{array}{l}.0038076^{*} \\
2.05\end{array}$ \\
\hline No. Of Ind. Director & $\begin{array}{l}-.0004068 \\
-0.58\end{array}$ & & $\begin{array}{l}-.0003521 \\
-0.52 \\
\end{array}$ & $\begin{array}{l}-.0003851 \\
-0.58 \\
\end{array}$ & $\begin{array}{l}-.0001729 \\
-0.24 \\
\end{array}$ \\
\hline Audit Committee Meeting & $\begin{array}{l}-.0000462 \\
-0.34\end{array}$ & & $\begin{array}{l}-.0000446 \\
-0.34\end{array}$ & $\begin{array}{l}-.0000313 \\
-0.25\end{array}$ & $\begin{array}{l}-.0000479 \\
-0.36\end{array}$ \\
\hline Foreign Ownership & $\begin{array}{l}.0079067 \\
1.21\end{array}$ & & $\begin{array}{l}.0080059 \\
1.26\end{array}$ & $\begin{array}{l}.0057225 \\
0.96\end{array}$ & $\begin{array}{l}.0086149 \\
1.36\end{array}$ \\
\hline \multicolumn{6}{|l|}{ Management Quality: } \\
\hline Inefficiency & & $\begin{array}{l}- \\
.0067991^{*} \\
-3.49\end{array}$ & $\begin{array}{l}-.006643^{*} \\
-3.45\end{array}$ & $\begin{array}{l}- \\
.0067598^{*} \\
-3.75\end{array}$ & $\begin{array}{l}-.0063805^{*} \\
-3.30\end{array}$ \\
\hline \multicolumn{6}{|l|}{ Macroeconomic Variable: } \\
\hline GDP & & & & & $\begin{array}{l}-.181051 \\
-1.35\end{array}$ \\
\hline Inflation & & & & & $\begin{array}{l}.0712755 \\
1.52 \\
\end{array}$ \\
\hline \multicolumn{6}{|l|}{ Control Variable: } \\
\hline Loan Growth & $\begin{array}{l}-7.29 \mathrm{e}-08 \\
-0.17\end{array}$ & $\begin{array}{l}-1.62 \mathrm{e}-07 \\
-0.38\end{array}$ & $\begin{array}{l}-4.69 \mathrm{e}-08 \\
-0.11\end{array}$ & $\begin{array}{l}-1.49 \mathrm{e}-07 \\
-0.39\end{array}$ & $\begin{array}{l}-4.89 \mathrm{e}-08 \\
-0.12\end{array}$ \\
\hline AD Ratio & $\begin{array}{l}.0165366^{*} \\
2.18\end{array}$ & $\begin{array}{l}.0167721^{*} \\
2.29\end{array}$ & $\begin{array}{l}.0158338 \\
2.15 \\
\end{array}$ & $\begin{array}{l}-.0028644 \\
-0.35 \\
\end{array}$ & $\begin{array}{l}.0156862^{*} \\
2.09\end{array}$ \\
\hline Equity-Total Asset & $\begin{array}{l}- \\
.1165936^{*} \\
-10.04 \\
\end{array}$ & $\begin{array}{l}- \\
.0091166^{*} \\
-8.255 \\
\end{array}$ & $\begin{array}{l}-.1493223^{*} \\
-10.12\end{array}$ & $\begin{array}{l}-.163438^{*} \\
-10.32\end{array}$ & $\begin{array}{l}-.1619044^{*} \\
-9.93\end{array}$ \\
\hline Bank Size & $\begin{array}{l}- \\
.0094547^{*} \\
-5.03\end{array}$ & $\begin{array}{l}- \\
.1580361^{*} \\
-10.87^{*} \\
\end{array}$ & $\begin{array}{l}-.0095051^{*} \\
-5.20\end{array}$ & $\begin{array}{l}-.0032087 \\
-0.86\end{array}$ & $\begin{array}{l}-.0051915 \\
-1.68\end{array}$ \\
\hline $\begin{array}{l}\text { Bank Effect } \\
\text { Time Effect }\end{array}$ & $\begin{array}{l}\text { Yes } \\
\text { No }\end{array}$ & $\begin{array}{l}\text { Yes } \\
\text { No }\end{array}$ & $\begin{array}{l}\text { Yes } \\
\text { No }\end{array}$ & $\begin{array}{l}\text { Yes } \\
\text { Yes }\end{array}$ & $\begin{array}{l}\text { Yes } \\
\text { No }\end{array}$ \\
\hline $\begin{array}{l}\text { R-sq: Within = } \\
\text { Between }= \\
\text { Overall }=\end{array}$ & $\begin{array}{l}0.5113 \\
0.9413 \\
0.3917\end{array}$ & $\begin{array}{l}0.5156 \\
0.9524 \\
0.4392 \\
\end{array}$ & $\begin{array}{l}0.6371 \\
0.9682 \\
0.3752 \\
\end{array}$ & $\begin{array}{l}0.5400 \\
0.9464 \\
0.4099\end{array}$ & $\begin{array}{l}0.5477 \\
0.9628 \\
0.4130\end{array}$ \\
\hline Prob $>F=$ & 0.0000 & 0.0000 & 0.0000 & 0.0000 & 0.0000 \\
\hline $\begin{array}{l}\text { No. of Obs. } \\
\text { No. of Groups }\end{array}$ & $\begin{array}{l}100 \\
10\end{array}$ & $\begin{array}{l}100 \\
10 \\
\end{array}$ & $\begin{array}{l}100 \\
10\end{array}$ & $\begin{array}{l}100 \\
10\end{array}$ & $\begin{array}{l}100 \\
10 \\
\end{array}$ \\
\hline
\end{tabular}


In Model-5, we incorporate macroeconomic variable GDP and Inflation. Here, we can see that inflation has a positive relationship with bank performance. The higher inflation rate increases the loan rate which increases the spread. Thus higher inflation increases bank's profitability.

On the other hand, GDP is supposed to have a positive relationship with bank performance (ROA). But here in the model-5, we have found a negative relationship. The reason behind this unexpected result is the higher loan default rate.

Table 9: Determinant of Bank Performance Measured by ROE

\begin{tabular}{|c|c|c|c|c|c|}
\hline Explanatory Variable & Model-1 & Model-2 & Model-3 & Model-4 & Model-5 \\
\hline \multicolumn{6}{|l|}{ Corporate Governance: } \\
\hline Board Size & $\begin{array}{l}.0060029^{*} \\
2.87\end{array}$ & & $\begin{array}{l}.0059067^{*} \\
2.81\end{array}$ & $\begin{array}{l}.0024346 \\
1.21\end{array}$ & $\begin{array}{l}.0055317 \\
* 2.58\end{array}$ \\
\hline $\begin{array}{l}\text { Audit } \\
\text { Functionality }\end{array}$ & $\begin{array}{l}-.011035 \\
-0.65\end{array}$ & & $\begin{array}{l}-.0108008 \\
-0.63\end{array}$ & $\begin{array}{l}.008351 \\
0.52\end{array}$ & $\begin{array}{l}-.010851 \\
-0.64\end{array}$ \\
\hline No. Of Ind. Director & $\begin{array}{l}-.0015635 \\
-0.25\end{array}$ & & $\begin{array}{l}-.0014571 \\
-0.69\end{array}$ & $\begin{array}{l}.0003474 \\
0.06\end{array}$ & $\begin{array}{l}-.0033785 \\
-0.52\end{array}$ \\
\hline Audit Committee Meeting & $\begin{array}{l}.000851 \\
-0.69\end{array}$ & & $\begin{array}{l}.0811898 \\
1.38\end{array}$ & $\begin{array}{l}.0004302 \\
0.38\end{array}$ & $\begin{array}{l}-.0006944 \\
-0.57\end{array}$ \\
\hline Foreign Ownership & $\begin{array}{l}.0809969 \\
1.38\end{array}$ & & $\begin{array}{l}.0811898 \\
1.38\end{array}$ & $\begin{array}{l}.0561274 \\
1.03\end{array}$ & $\begin{array}{l}.0874015 \\
1.50\end{array}$ \\
\hline \multicolumn{6}{|l|}{ Management Quality: } \\
\hline Inefficiency & & $\begin{array}{l}-.0168258 \\
-0.93 \\
\end{array}$ & $\begin{array}{l}-.0129114 \\
-0.72 \\
\end{array}$ & $\begin{array}{l}-.0046692 \\
-0.28 \\
\end{array}$ & $\begin{array}{l}-.0074486 \\
-0.42 \\
\end{array}$ \\
\hline \multicolumn{6}{|l|}{ Macroeconomic Variable } \\
\hline GDP & & & & & $\begin{array}{l}-.181051 \\
-1.35\end{array}$ \\
\hline Inflation & & & & & $\begin{array}{l}.0712755 \\
1.52\end{array}$ \\
\hline \multicolumn{6}{|l|}{ Control Variable: } \\
\hline Loan Growth & $\begin{array}{l}-1.30 \mathrm{e}-06 \\
-0.33\end{array}$ & $\begin{array}{l}-1.74 \mathrm{e}-06 \\
-0.44\end{array}$ & $\begin{array}{l}-1.25 e-06 \\
-0.32\end{array}$ & $\begin{array}{l}-2.78 \mathrm{e}-06 \\
-0.79\end{array}$ & $\begin{array}{l}-3.229769 \\
-2.62\end{array}$ \\
\hline AD Ratio & $\begin{array}{l}.2230291^{*} \\
3.26\end{array}$ & $\begin{array}{l}.2359405^{*} \\
3.46\end{array}$ & $\begin{array}{l}.2216631^{*} \\
3.24\end{array}$ & $\begin{array}{l}.0361143 \\
0.48\end{array}$ & $\begin{array}{l}.1560021 \\
0.36\end{array}$ \\
\hline Equity-Total Asset & $\begin{array}{l}.476109 * \\
4.55\end{array}$ & $\begin{array}{l}- \\
.0667908^{*} \\
-6.49\end{array}$ & $\begin{array}{l}.4124969^{*} \\
3.01\end{array}$ & $\begin{array}{l}.1352998 \\
0.93\end{array}$ & $\begin{array}{l}-1.44 \mathrm{e}-06^{*} \\
-0.38\end{array}$ \\
\hline Bank Size & $\begin{array}{l}- \\
.0505414^{*} \\
-2.98\end{array}$ & $\begin{array}{l}.408895 * \\
3.02\end{array}$ & $\begin{array}{l}-.0506393^{*} \\
-2.98\end{array}$ & $\begin{array}{l}.106258 \\
3.09\end{array}$ & $\begin{array}{l}.2500005 \\
3.62\end{array}$ \\
\hline $\begin{array}{l}\text { Bank Effect } \\
\text { Time Effect }\end{array}$ & $\begin{array}{l}\text { Yes } \\
\text { No }\end{array}$ & $\begin{array}{l}\text { Yes } \\
\text { No }\end{array}$ & $\begin{array}{l}\text { Yes } \\
\text { No }\end{array}$ & $\begin{array}{l}\text { Yes } \\
\text { Yes }\end{array}$ & $\begin{array}{l}\text { Yes } \\
\text { No }\end{array}$ \\
\hline R-sq: $\begin{aligned} \text { Within } & = \\
\text { Between } & = \\
\text { Overall } & =\end{aligned}$ & $\begin{array}{l}0.3574 \\
0.0060 \\
0.1425 \\
\end{array}$ & $\begin{array}{l}0.3188 \\
0.0345 \\
0.1909 \\
\end{array}$ & $\begin{array}{l}0.3591 \\
0.0063 \\
0.1558 \\
\end{array}$ & $\begin{array}{l}0.5069 \\
0.0036 \\
0.1111 \\
\end{array}$ & $\begin{array}{l}0.3822 \\
0.0000 \\
0.1443 \\
\end{array}$ \\
\hline Prob $>F=$ & 0.0004 & 0.0043 & 0.0011 & 0.0000 & 0.0022 \\
\hline $\begin{array}{l}\text { No. of Obs. } \\
\text { No. of Groups }\end{array}$ & $\begin{array}{l}225 \\
25\end{array}$ & $\begin{array}{l}225 \\
25\end{array}$ & $\begin{array}{l}225 \\
25\end{array}$ & $\begin{array}{l}225 \\
25\end{array}$ & $\begin{array}{l}225 \\
25\end{array}$ \\
\hline
\end{tabular}


Model-1 shows the relationship between corporate governance and bank's performance (ROE). In this model, four control variables (Loan growth, AD ratio, Equity to total asset ratio, bank size) have also been included. From the Hausman test, we have found that the fixed effect model is appropriate for this model. Here, we can see that pob $>F=0.0000$ which means that the model is ok.

Model-2 shows the relationship between management quality and bank's performance. In this model, four control variables (Loan growth, AD ratio, Equity to total asset ratio, bank size) have also been included. From the Hausman test, we have found that the fixed effect model is appropriate for this model. Here, we can see that Prob $>\mathrm{F}=0.0000$ which means that the model is ok. Here we have found that AD ratio, equity to total asset and bank size have significant relationship with ROE. Inefficiency is negatively correlated with ROE that means the lower the inefficiency the better will be the bank performance.

In Model-3, we have tried to find the relationship among corporate governance, management quality and bank's performance. Here, we have found that better corporate governance and management quality increase the bank profitability.

In Model-4, we have considered the time effect and found same result as we found in model-3.

In Model-5, we incorporate macroeconomic variable GDP and Inflation. Here, we can see that inflation has a positive relationship with bank performance. The higher inflation rate increases the loan rate which increases the spread. Thus higher inflation increases bank's profitability.

On the other hand, GDP is supposed to have a positive relationship with bank performance (ROE). But here in the model-5, we have found a negative relationship. The reason behind this unexpected result is the higher loan default rate.

Table 10: Determinant of Bank Performance Measured by NIM

\begin{tabular}{|c|c|c|c|c|c|}
\hline Explanatory Variable & Model-1 & Model-2 & Model-3 & Model-4 & Model-5 \\
\hline \multicolumn{6}{|l|}{ Corporate Governance: } \\
\hline Board Size & $\begin{array}{l}.0002325 \\
1.42 \\
\end{array}$ & & $\begin{array}{l}.0002019 \\
1.26 \\
\end{array}$ & $\begin{array}{ll}-.0000213 & -- \\
0.13 & \\
\end{array}$ & $\begin{array}{l}.0000954 \\
.59\end{array}$ \\
\hline $\begin{array}{l}\text { Audit Committee } \\
\text { Functionality }\end{array}$ & $\begin{array}{l}-.0014884 \\
-1.12 \\
\end{array}$ & & $\begin{array}{l}-.0014137 \\
-1.08 \\
\end{array}$ & $\begin{array}{l}-.0026596^{*} \\
-2.07\end{array}$ & $\begin{array}{l}-.0019758 \\
-1.52 \\
\end{array}$ \\
\hline No. Of Ind. Director & $\begin{array}{l}-.0005695 \\
-1.16\end{array}$ & & $\begin{array}{l}-.0005356- \\
1.11\end{array}$ & .00037280 .76 & $\begin{array}{l}-.0000877 \\
-0.18\end{array}$ \\
\hline $\begin{array}{ll}\text { Audit } & \text { Committee } \\
\text { Meeting } & \\
\end{array}$ & $\begin{array}{l}.0000478 \\
0.50\end{array}$ & & .52 & $\begin{array}{l}.0000526 \\
0.58\end{array}$ & $\begin{array}{l}.0000294 \\
0.32\end{array}$ \\
\hline Foreign Ownership & $\begin{array}{l}.000984 \\
-0.21\end{array}$ & & $\begin{array}{l}-.0009225 \\
.20\end{array}$ & .0016402 .38 & $\begin{array}{l}-.0006047 \\
-0.14 \\
\end{array}$ \\
\hline \multicolumn{6}{|l|}{ Management Quality: } \\
\hline Inefficiency & & $\begin{array}{l}-.0043121 \\
-3.16\end{array}$ & $\begin{array}{l}-.0041167^{*} \\
-3.01\end{array}$ & $\begin{array}{l}-.0032773^{*}- \\
2.49\end{array}$ & $\begin{array}{l}-.0042429 \\
-3.14 \\
\end{array}$ \\
\hline \multicolumn{6}{|l|}{$\begin{array}{l}\text { Macroeconomic } \\
\text { Variable }\end{array}$} \\
\hline GDP & & & & & $\begin{array}{l}.0361877 \\
0.39\end{array}$ \\
\hline Inflation & & & & & $\begin{array}{l}.0911663^{*} \\
2.78\end{array}$ \\
\hline
\end{tabular}




\begin{tabular}{|l|l|l|l|l|l|}
\hline Control Variable: & & & & & \\
\hline Loan Growth & $-4.72 \mathrm{e}-07$ & $-4.70 \mathrm{e}-07$ & $-4.55 \mathrm{e}-07$ & $-3.76 \mathrm{e}-07$ & $-4.40 \mathrm{e}-07$ \\
& -1.55 & -1.59 & -1.53 & -1.34 & -1.51 \\
\hline AD Ratio & $.0127962^{*}$ & $.0135528^{*}$ & .0123607 & $.0131756^{*}$ & .0094635 \\
& 2.40 & 2.64 & 2.36 & 2.19 & 1.80 \\
\hline Equity-Total Asset & $.0252347^{*}$ & - & .0049523 & -.0186285 & -.0028834 \\
& 3.08 & $.0023806^{*}$ & .47 & -1.61 & -.25 \\
& & -3.08 & & & \\
\hline Bank Size & -.0004027 & .0075613 & -.000434 & $.006929^{*} .012$ & .0013142 \\
& -0.30 & .74 & -.33 & & 0.61 \\
\hline Bank Effect & & & & & \\
Time Effect & Yes & Yes & Yes & Yes & Yes \\
\hline R-sq: Within $=$ & No & No & No & Yes & No \\
Between $=$ & 0.1984 & 0.2148 & 0.2349 & 0.3603 & 0.2710 \\
Overall $=$ & 0.0647 & 0.0857 & 0.0570 & 0.1718 & 0.1024 \\
\hline Prob $>\mathrm{F}=$ & 0.1001 & 0.1358 & 0.1208 & 0.2393 & 0.1679 \\
\hline No. of Obs. & 0.0000 & 0.0043 & 0.0011 & 0.0000 & 0.0022 \\
No. of Groups & 225 & 225 & 225 & 225 & 225 \\
\hline
\end{tabular}

Model-1 shows the relationship between corporate governance and bank's performance (NIM). In this model, four control variables (Loan growth, AD ratio, Equity to total asset ratio, bank size) have also been included. From the Hausman test, we have found that the fixed effect model is appropriate for this model. Here, we can see that pob $>F=0.0000$ which means that the model is ok.

Model-2 shows the relationship between management quality and bank's performance. In this model, four control variables (Loan growth, AD ratio, Equity to total asset ratio, bank size) have also been included. From the Hausman test, we have found that the fixed effect model is appropriate for this model. Here, we can see that Prob $>F=0.0000$ which means that the model is ok. Here we have found that AD ratio and equity to total asset have significant relationship with NIM. Inefficiency is negatively correlated with NIM that means the lower the inefficiency the better will be the bank performance.

In Model-3 we have tried to find the relationship among corporate governance, management quality and bank's performance. Here, we have found that better corporate governance and management quality increase the bank profitability.

In Model-4, we have considered the time effect and found same result as we found in model-3.

In Model-5, we incorporate macroeconomic variable GDP and Inflation. Here, we can see that inflation has a positive relationship with bank performance. The higher inflation rate increases the loan rate which increases the spread. Thus higher inflation increases bank's profitability.

On the other hand, GDP is supposed to have a positive relationship with bank performance (NIM). But here in the model-5, we have found a negative relationship. The reason behind this unexpected result is the higher loan default rate. 


\section{RESEARCH Findings}

This section illustrates the findings revealed from this study. The findings are discussed below:

- Firstly, among the three profitability measures, ROA model generates the highest explanatory power having a value of $\mathrm{r}$ square of above $90 \%$. This finding serve as an indicator that the bank specific and macroeconomic variables selected for this study provide a better description of ROA rather than net interest margin (NIM) and ROE.

- Among all the bank specific determinants, board size, audit committee meeting and foreign ownership have positive relationship with bank's performance. That means the increase in these variables increases the profitability of commercial banks.

- $\quad$ On the other hand, favorable macroeconomic environment seems to stimulate higher profits. Specifically, inflation is observed to have positive relationship with bank performance.

- Like inflation, higher growth rate of GDP is supposed to have a strong positive relationship with the performance measures. But actual result shows a negative relationship because bank profitability is not increasing with growth of loan and business. The reason behind this situation is the activities of dishonest businessmen who are not paying their debt obligation properly.

\section{Conclusion}

This study specifies an empirical framework in an attempt to investigate the bank specific and macroeconomic determinants of commercial bank performance in Bangladesh, measured by return on assets (ROA), return on equity (ROE) and net interest margins (NIM). A balanced panel data set of 100 observations of 10 commercial banks in Bangladesh, covering the period 2009 to 2018, provided the basis for the econometric analysis. The aim is to combine the literature on bank specific and industry specific factors with the literature on bank specific and macroeconomic factors impact on bank performance, with the purpose of examining the determinants that influence the profitability of the banks.

\section{References}

Ahmad, I. (1994). Modern banking - A comparative approach: a case study of Iran, Malaysia, Pakistan and Sudan, with special reference to "Musharaka" and "Modaraba" financing, M. Comparative Laws, International Islamic University Malaysia.

Becker, W. E. (1995). Statistics: For Business and Economics, U.S: International Thomson Publishing.

Georgiou, M. N. (2010). Converging Bank Profitability (2000-2006) (February 21). SSRN Electronic Journal. https://doi.org/10.2139/ssrn.1556668

Goddard, J., Molyneux, P. and Wilson, J. (2004). The profitability of European banks: A cross-sectional and dynamic panel analysis. The Manchester School, 72(3), 363-381. https://doi.org/10.1111/j.1467-9957.2004.00397.x

Haron, S. (1996). Competition and other external determinants of the profitability of Islamic banks. Islamic Economic Studies, 4(1), 49-64. http:/ / iesjournal.org/english/Docs/134.pdf 
Hasan, Z. (2004). Measuring efficiency of Islamic banks: criteria, methods, and social priorities. MPRA Paper 2977, University Library of Munich, Germany. https://ideas.repec.org/p/pra/mprapa/2977.html

Islam, M. M. (2003). Development and performance of domestic and foreign banks in GCC countries. Managerial Finance, 29(2/3), 4272. https://doi.org/10.1108/03074350310768689

Naceur, S. B. (2003). The determinants of the Tunisian banking industry profitability: Panel evidence. Paper presented at the Economic Research Forum (ERF) 10th Annual Conference, Marrakesh-Morocco, 16-18 December, 1-17. https://www.mafhoum.com/press6/174E11.pdf

Swamy, V. (2012). Determinants of Bank Asset Quality and Profitability - An Empirical Assessment. SSRN Electronic Journal. https://doi.org/10.2139/ssrn.2126761

Uzhegova, O. (2010). The Relative Importance of Bank-Specific Factors for Bank Profitability in Developed and Emerging Economies. SSRN Electronic Journal. 


\section{APPENDIX}

\section{Research Questions}

The paper aims at providing answers to the following questions:

- What are the macroeconomic factors that can exert influence on the profitability of commercial banks?

- What is the impact of GDP growth on the profitability of commercial banks?

- What is the impact of inflation rate on the profitability of commercial banks?

- What is the impact of board size on the profitability of commercial banks?

- What is the impact of number of independent directors on the profitability of commercial banks?

- What is the impact of audit committee functionality on the profitability of commercial banks?

- What is the impact of foreign ownership on the profitability of commercial banks? 